\title{
LANDSCAPE COEFFICIENT TO DETERMINE WATER REQUIREMENT FOR A COMPUTER MODEL
}

\author{
A. A. Radwan', M. N. El Awady' ${ }^{2}$ K. F. El Bagoury ${ }^{3}$, \\ W. M. Sultan ${ }^{4}$, A.K. Mohamed ${ }^{5}$
}

\begin{abstract}
The two factors used to determine landscape water requirement $\left(E T_{L}\right)$, the landscape coefficient and reference evapotranspiration, are solely responsible for producing differences in water loss estimates. For plantings in the same location (i.e., where the same ETo values will be used), the differences will arise solely from the landscape coefficient. To produce useful estimates of water loss, therefore, it is important to carefully determine the value of $K_{L}$.

In agriculture, irrigation water requirements are well established for many crops. In urban landscapes, irrigation requirements have been determined for turf grasses, but not for most landscape species. This study adapts this method for application to landscape plantings.

The method used for estimating water needs for landscape plantings is basically the same as that used for crops and turfgrasses. One key change, however, has been made: instead of using the crop coefficient $\left(K_{c}\right)$, a landscape coefficient $\left(K_{L}\right)$ has been substituted.

The main objective of this work is building computer program to determine water requirement for some multi-plant landscape and modern system for their irrigation.

Audit in the accounts of landscape coefficient $\left(K_{L}\right)$ closest to the prevailing conditions by application "Landscape Irrigation Scheduling" program outputs, led to save water use by $60 \%$ for landscape plants in

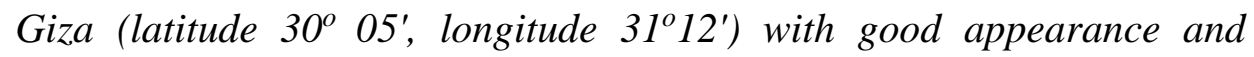
growth for landscape plants and grass.
\end{abstract}

\footnotetext{
1. Grad. Student

2 -Prof. Emt. , Ag. Eng., Ain-Shams Univ.,Col. Ag.

3 -Ascoc, Prof. of Ag. Eng., Ain-Shams Univ.,Col. Ag.

4- Res. Ag. Eng., Inst. of Ag. Eng. Res., ARC.

5 -Asst. Prof. Hortic, Ain-Shams Univ.
} 
The program could offer a simple tool for planning ornamental plants and turf grass water requirements for landscape projects.

Keywords: Water requirement - Landscape Coefficient Evapotranspiration - Microclimate - Ornamental plants -Landscape .

\section{INTRODUCTION}

7 urfgrasses and ornamental plants are considered an integral part of landscape ecological systems worldwide, which provide

1 esthetic value. (Romero and Dukes, 2009). Landscape design means choosing the right tree, shrub or flower for a particular place. (Streich, 2003).

WUCOLS (2000) and Awady et al. (2003) used two formulas to estimate water needs for landscape plantings: - The landscape evapotranspiration formula and, The landscape coefficient formula. Water needs of landscape plantings $\left(\mathrm{ET}_{\mathrm{L}}\right)$ can be estimated using the landscape evapotranspiration formula:

$$
\mathrm{ET}_{\mathrm{L}}=\mathrm{K}_{\mathrm{L}} \times \mathrm{ET}_{\mathrm{o}}
$$

Landscape Evapotranspiration $=$ Landscape Coefficient $\times$ Reference Evapotranspiration $\mathrm{K}_{\mathrm{L}}=\mathrm{K}_{\mathrm{s}} \times \mathrm{K}_{\mathrm{mc}} \times \mathrm{K}_{\mathrm{d}}$

where:

$\mathrm{K}_{\mathrm{L}}=$ Landscape coefficient .

$\mathrm{K}_{\mathrm{s}}=$ Adjustment factor representing characteristics for a particular plant species.

$\mathrm{K}_{\mathrm{mc}}=$ Adjustment factor for microclimate influences upon the planting .

$\mathrm{K}_{\mathrm{d}}=$ Adjustment factor for plant density (All factor are dimensionless).

\section{Costello et al.(1993)}

Reference ET $\left(\mathrm{ET}_{\mathrm{o}}\right)$ is defined as the ET from a 3-6" tall cool season grass that completely covers the ground, and is supplied with adequate water. This turf surface, equivalent to a very tall cool season grass rough on a golf course, is known as the reference crop or reference surface. In the real world, $\mathrm{ET}_{\mathrm{o}}$ is not routinely measured, but instead computed from a mathematical formula such as the Penman or Penman-Monteith Equation. Weather data are required for the Penman computation of $\mathrm{ET}_{\mathrm{o}}$. (Brown, 2000). 
The use of a landscape coefficient $\left(\mathrm{K}_{\mathrm{L}}\right)$ is a relatively new concept. The advantage of using $\mathrm{K}_{\mathrm{L}}$ for landscapes instead of the traditional "crop coefficient" $\left(\mathrm{K}_{\mathrm{c}}\right)$ is that the $\mathrm{K}_{\mathrm{L}}$ value can be adjusted for the microclimate $\left(\mathrm{K}_{\mathrm{mc}}\right)$ and planting density $\left(\mathrm{K}_{\mathrm{d}}\right)$ impacts upon the plant water requirement as well as for the specific species $\left(\mathrm{K}_{\mathrm{s}}\right)$. However, $\mathrm{K}_{\mathrm{L}}$ cannot be used if its $\mathrm{K}_{\mathrm{s}}$ factor is unknown. In some regions of the country, only information on $\mathrm{K}_{\mathrm{c}}$ may be available. (IA.2005)

\section{MATERIALS AND METHODS}

\section{Landscape Irrigation Scheduling program (LIS).}

Landscape Irrigation Scheduling program (LIS) flow chart ( Fig.1).

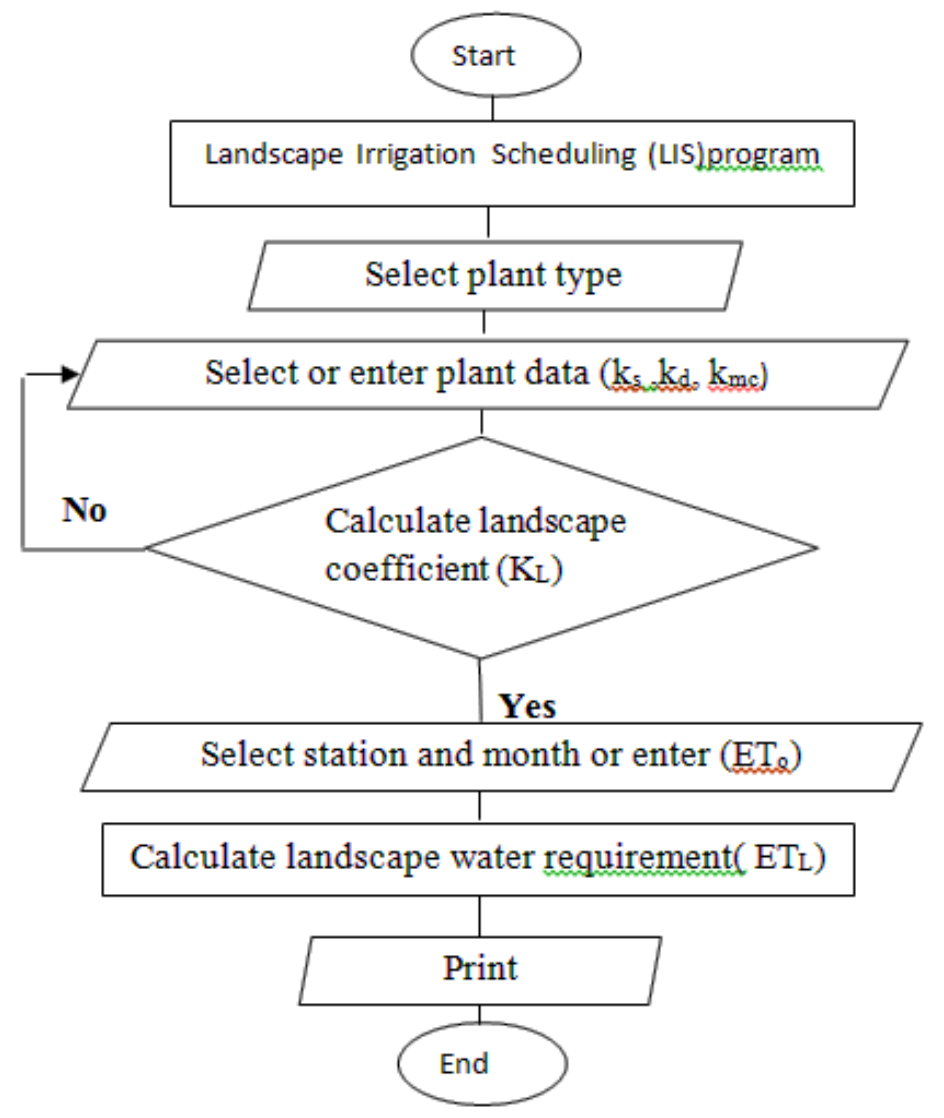

Fig. 1. Flow chart components of the" Landscape Irrigation Scheduling "(LIS)" program.

This program is set up for this work. Its input are as follows:

To register the program, enter user name and password, and click login. 


\section{Plant Type.}

The vegetation type is selected because decision must be made on the factors of vegetation water use, vegetation density and area microclimate. You can search the plant name to know the plant of any category (Fig.2).

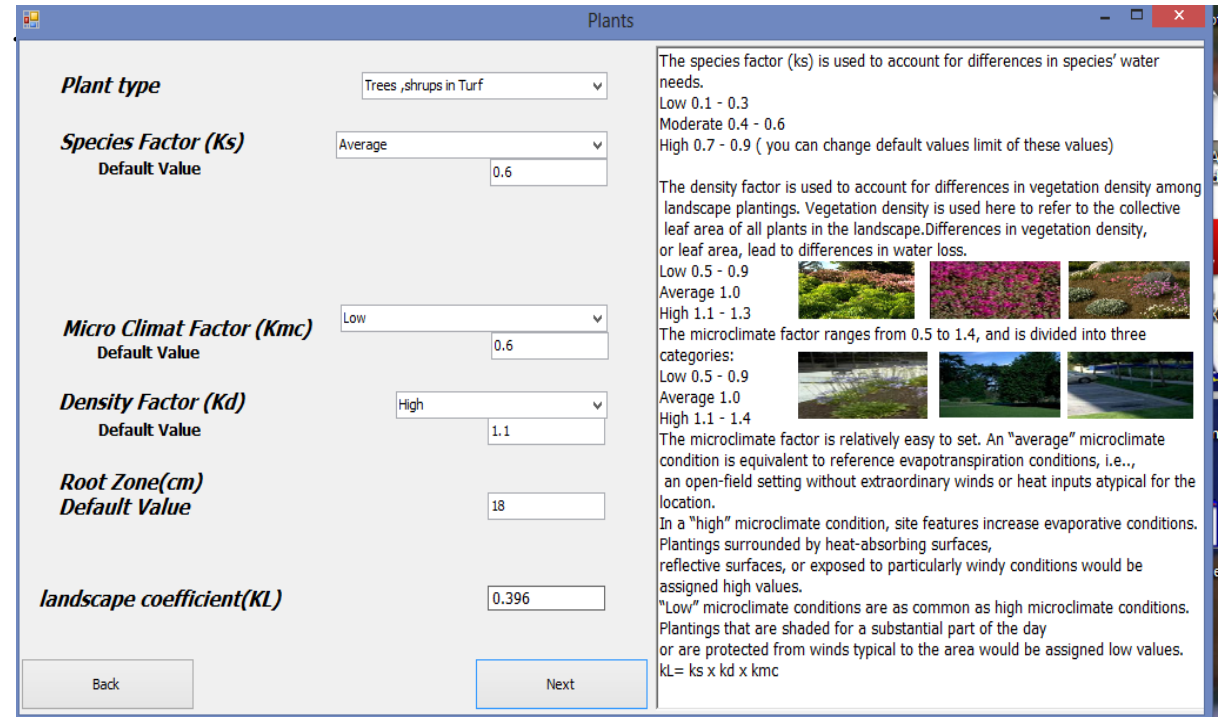

Fig.2.Plant type.

\section{Evapotranspiration (ET).}

LIS program is based on historical $\mathrm{ET}_{\mathrm{o}}$. One can irrigate fairly accurately using historic $\mathrm{ET}_{\mathrm{o}}$ data, Thus, $\mathrm{ET}_{\mathrm{o}}$ information is available as historical data from "Central Laboratory for Agricultural Climate". These values of $\mathrm{ET}_{\mathrm{o}}$ can be changed if desired and entered (Fig.3).

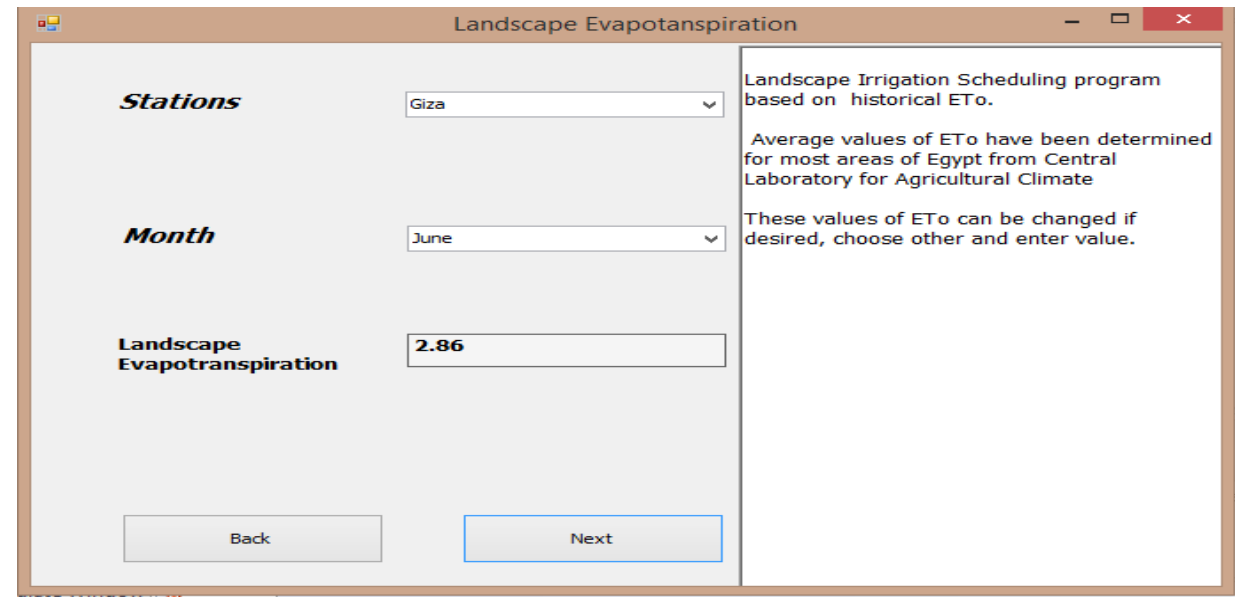

Fig.3.Landscape evapotranspiration. 


\section{Landscape water requirement.}

The landscape water use $\left(\mathrm{ET}_{\mathrm{L}}\right)$ can be calculated for a specific plant by using a reference evapotranspiration rate $\left(\mathrm{ET}_{\mathrm{o}}\right)$, and applying a landscape coefficient $\left(\mathrm{K}_{\mathrm{L}}\right)$ to convert the reported $\mathrm{ET}_{\mathrm{o}}$ to $\mathrm{ET}_{\mathrm{L}}$.

A site audit was conducted on the study area with the results shown in the table 1 .

Table 1: Site audit conducted on the study area.

\begin{tabular}{|c|c|c|c|c|}
\hline No. & Cases Attribute & Case1 & Case2 & Case3 \\
\hline 1 & $\begin{array}{l}\text { Landscape } \quad \text { area } \\
(\mathrm{A})\left(\mathrm{m}^{\wedge} 2\right)\end{array}$ & 54 & 90 & 14 \\
\hline 2 & Irrigation system & $\begin{array}{l}\text { Fixed Spray } \\
\text { Head }\end{array}$ & $\begin{array}{l}\text { Fixed Spray } \\
\text { Head }\end{array}$ & $\begin{array}{l}\text { Drip in line } \\
\text { (Bed area) }\end{array}$ \\
\hline 3 & $\begin{array}{l}\text { Precipitation rate } \\
(\mathrm{PR}) \mathrm{mm} . / \mathrm{h} \text {. }\end{array}$ & 96.17 & 65.39 & 16 \\
\hline 4 & $\begin{array}{l}\text { lower-quarter } \\
\text { distribution } \\
\text { uniformity } \\
\left(\mathrm{DU}_{\mathrm{LQ}}\right) \% \text { Emission } \\
\text { uniformity(EU)\% }\end{array}$ & 45.9 & 40.2 & 91.5 \\
\hline 5 & Soil Type & Clay & Clay & Sandy \\
\hline 6 & Plant Type & $\begin{array}{l}\text { Trees and } \\
\text { shrubs in turf }\end{array}$ & $\begin{array}{l}\text { Trees and } \\
\text { new shrubs } \\
\text { in new turf }\end{array}$ & $\begin{array}{l}\text { Mixture } \\
\text { (Sedum } \\
\text { spp.and new } \\
\text { shrubs) }\end{array}$ \\
\hline 7 & Root Zone Depth(cm) & 18 & 15 & 15 \\
\hline 8 & Plant Ks & Average & Average & Average \\
\hline 9 & Microclimate & $\begin{array}{ll}\text { Full shade } & \text { (south } \\
\text { side of } & \text { office } \\
\text { building) } & \end{array}$ & $\begin{array}{l}\text { Full shade } \\
\text { (south side } \\
\text { of office } \\
\text { building) }\end{array}$ & $\begin{array}{l}\text { Full shade } \\
\text { (south side of } \\
\text { office } \\
\text { building) }\end{array}$ \\
\hline 10 & Density & High & Average & Low \\
\hline
\end{tabular}

\section{RESULTS AND DISCUSSION}

\section{Average daily historical reference evapotranspiration.}

The historical reference ET $\left(\mathrm{ET}_{\mathrm{o}}\right)$ for the irrigation season (Jan. through

Dec.) is provided in table 2. These values are the for experiment only.

Table 2: Average daily historical reference evapotranspiration.

\begin{tabular}{|c|c|c|c|c|c|c|c|c|c|c|c|c|}
\hline $\begin{array}{l}\text { Average } \\
\text { daily } \\
\text { historical }\end{array}$ & 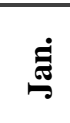 & $\dot{0}$ & $\dot{\vec{\Xi}}$ & $\dot{\vec{u}}$ & $\stackrel{\vec{g}}{\sum}$ & $\dot{\Xi}$ & $\dot{\Xi}$ & $\frac{000}{Z}$ & 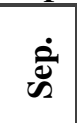 & $\dot{\mathscr{o}}$ & z & હٌّ \\
\hline $\begin{array}{l}\text { Reference } \\
\text { ETo } \\
\text { (mm/day.) }\end{array}$ & 2.2 & 2.7 & 4 & 5.14 & 6.43 & 7.21 & 6.8 & 6.12 & 5.5 & 4.54 & 3.27 & 2.2 \\
\hline
\end{tabular}




\section{Landscape coefficient $\left(K_{L}\right)$.}

Case1: comprised a mature planting of Dodonaea, Acalypha, Lantana camara and star jasmine in an amusement park in Doki. The planting is full, but shaded in the afternoon by an adjacent building. The building also blocks afternoon winds as typical for the area.

$\mathrm{k}_{\mathrm{s}}=0.6$

$$
\begin{array}{cc}
\mathrm{k}_{\mathrm{d}}=1.1 & \mathrm{k}_{\mathrm{mc}}=0.6 \\
\mathrm{~K}_{\mathrm{L}}=0.6 \times 1.1 \times 0.6=0.396 &
\end{array}
$$

Analysis: Species in this planting are in two different WUCOLS (Water Use Classification of Landscape Species) categories: low (Dodonaea ,Bougainvilla and Lantana camara), moderate (Star jasmine, Acalypha). To maintain the warm season turfgrass in good condition, a $\mathrm{k}_{\mathrm{s}}$ value of 0.6 is needed. This means, however, that both the Dodonaea ,Bougainvilla and Lantana camara will receive more water than they need. Obviously this is not a water-efficient planting. Since the canopy cover is $100 \%$ and all two vegetation types occur, this is a high density planting and a $\mathrm{k}_{\mathrm{d}}$ of 1.1 is assigned. Since the building shades the planting and protects it from wind, the microclimatic factor is low and a $\mathrm{k}_{\mathrm{mc}}$ value of 0.6 is assigned.

Case2: comprised new planting of Duranta repens and Hibiscus rosasinensis,. All plants were in a 1-liter plastic container, placed in shade by an adjacent building. Canopy cover was 20 to $30 \%$ but planting was in turf .Water supplied to meet turf needs was often not sufficient for new plants in turf. However, turf irrigation was likely to be sufficient for most species once established,

$\mathrm{k}_{\mathrm{s}}=0.6$

$$
\begin{array}{cc}
\mathrm{k}_{\mathrm{d}}=1.0 & \mathrm{k}_{\mathrm{mc}}=0.6 \\
\mathrm{~K}_{\mathrm{L}}=0.5 \times 1.0 \times 0.5=0.25 &
\end{array}
$$

Analysis: All species in this planting are classified as moderate in the WUCOLS list with a midrange value. To maintain the warm season turfgrass in good condition, a $\mathrm{k}_{\mathrm{s}}$ value of 0.6 was needed. Since this is a new planting and canopy cover is not full, it was placed in an average density category and assigned a $\mathrm{k}_{\mathrm{d}}$ value of 1.0. The micro climate factor is low and assigned a value of 0.6.

Case3: A new planting of Echinocactusgrusnii, Sedum spp. and Durantarepens were considered. All plants were in a 1-liter plastic container, planted in shade by an adjacent building. Canopy cover was 10 to $20 \%$. 


$$
\begin{array}{ccc}
\mathrm{k}_{\mathrm{S}}=0.5 & \mathrm{k}_{\mathrm{d}}=0.5 & \mathrm{k}_{\mathrm{mc}}=0.6 \\
& \mathrm{~K}_{\mathrm{L}}=0.5 \times 0.5 \times 0.5=0.15 &
\end{array}
$$

Analysis: Species in this planting were in two different WUCOLS categories: low (Echinocactusgrusnii, Sedum spp.), moderate (Durantarepens). To maintain the Durantarepens in good condition, a $\mathrm{k}_{\mathrm{s}}$ value of 0.5 is needed. Since this was a new planting and canopy cover is not full, it is placed in a low-density category and assigned a $\mathrm{k}_{\mathrm{d}}$ value of 0.5. The microclimate factor was low and assigned a value of 0.6.

These field examples should provide an understanding of how values for each of the landscape coefficient factors are assigned and used. In addition, an appreciation for the diversity of species, differences in vegetation density, and variation in microclimates which exist in landscapes should be realized. In many cases, there will be a different landscape coefficient for each irrigation zone.

\section{Average daily plant water requirement.}

Table 3 shows the average daily plant water requirement of each month of the experiment. Cases were base on the data for input to "LIS" program.

These calculations show that landscape irrigation water needs vary substantially. Estimates range from $1.08 \mathrm{~mm}$ /day to $2.86 \mathrm{~mm}$ /day for the

\begin{tabular}{|c|c|c|c|c|c|c|c|c|c|c|c|c|}
\hline Daily & 志 & $\dot{0}$ & $\dot{\vec{\Xi}}$ & $\ddot{\breve{z}}$ & $\dot{\vec{z}}$ & $\dot{\Xi}$ & $\dot{\Xi}$ & $\stackrel{\varphi 00}{Z}$ & 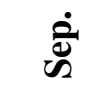 & $\dot{\tilde{\Xi}}$ & $\dot{z}$ & هัँ \\
\hline $\begin{array}{c}\mathrm{ET}_{\mathrm{L} . \text { daily }} \\
\text { (mm.) } \\
\text { Case } 1\end{array}$ & 0.87 & 1.07 & 1.58 & 2.04 & 2.55 & 2.86 & 2.69 & 2.44 & 2.18 & 1.98 & 1.30 & 0.87 \\
\hline $\begin{array}{c}\mathrm{ET}_{\mathrm{L} . \text { daily }} \\
\text { (mm.) } \\
\text { Case2 }\end{array}$ & 0.79 & 0.97 & 1.44 & 1.85 & 2.32 & 2.60 & 2.45 & 2.20 & 1.98 & 1.63 & 1.18 & 0.79 \\
\hline $\begin{array}{c}\text { ET }_{\mathrm{L} . \text { daily }} \\
\text { (mm.) } \\
\text { Case3 }\end{array}$ & 0.33 & 0.40 & 0.06 & 0.77 & 0.96 & 1.08 & 1.02 & 0.92 & 0.83 & 0.68 & 0.49 & 0.33 \\
\hline
\end{tabular}
month of July will more than a 2.5 -fold difference in this experiment only.

Table 3: Average daily plant water requirement. 


\section{Plant growth measurements.}

The growth index was determined in July to Dec. 2013 for (Dodonaea ,Acalyphagodseffiana, Lantana camara, ,Jasminum and Bougainvilla) as shrubs. The percentages of increase in the height of plants (shrubs) in July to Dec. 2013 were 51.08, 59.69, 41.96, 33.89, and 23.64\% for (Dodonaea. Acalyphagodseffiana, Lantana camara, ,Jasminum and Bougainvilla) resp. (Fig. 4).

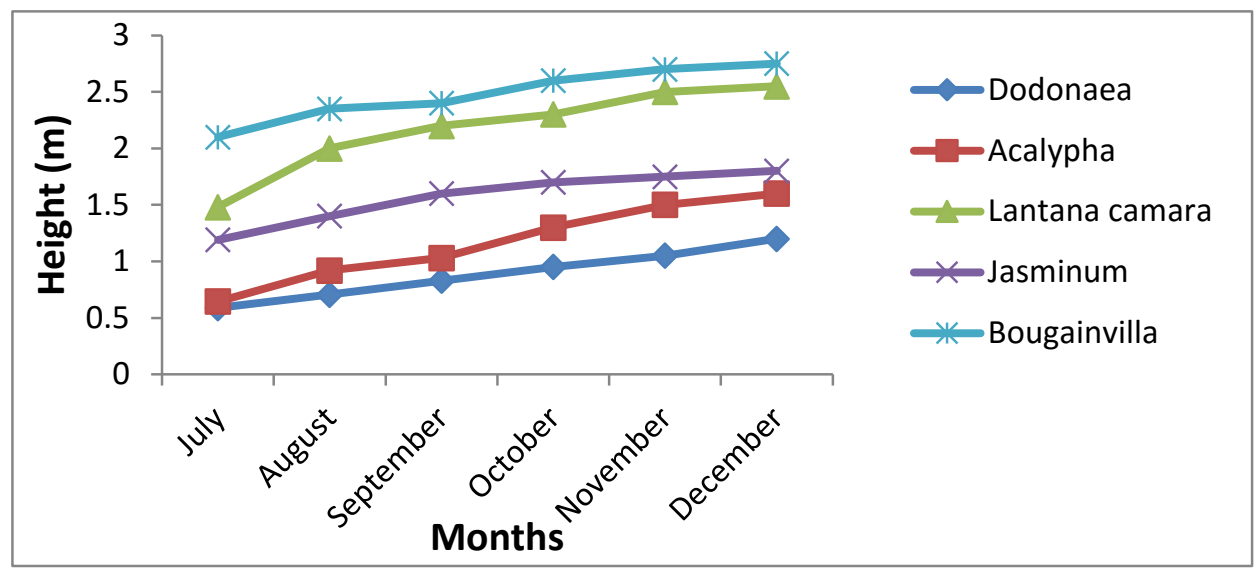

Fig. 4.Height (m.)determined in July to Dec.2013 for different plants.

The percentages of increase in the canopy area $\left(\mathrm{m}^{2}\right)$ of plants (shrubs) in July to Dec. 2013 were 55.17, 62.1, 49.28, 48.75, and 35.14\% for (Dodonaea ,Acalyphagodseffiana, Lantana camara, ,Jasminum and Bougainvilla) respectively (Fig. 5)

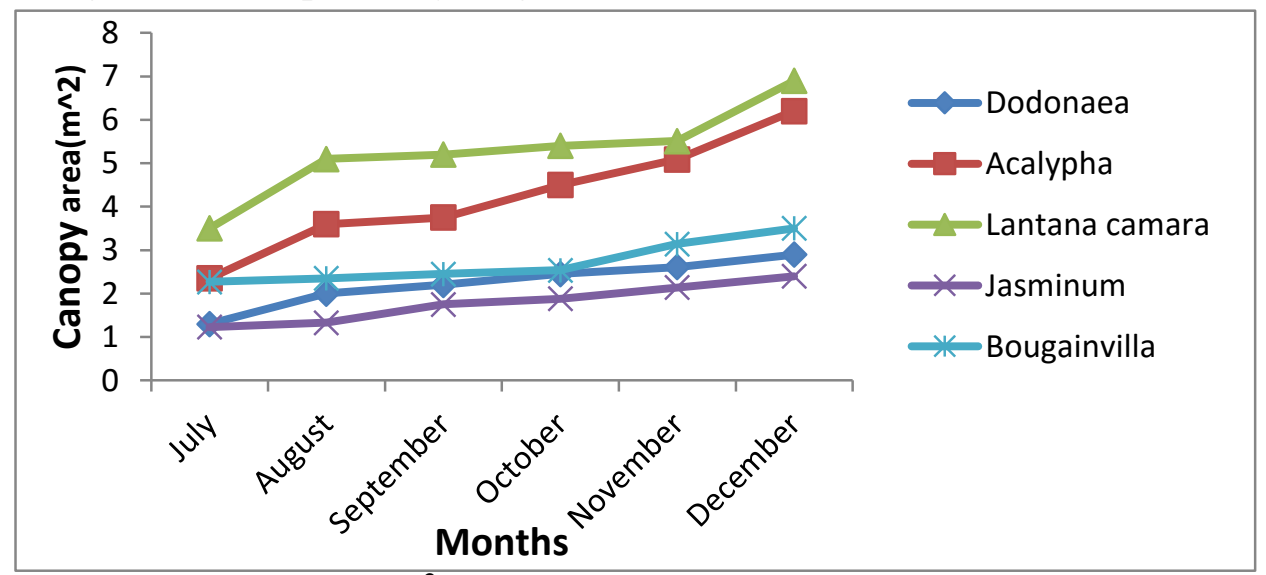

Fig. 5.Canopy area $\left(\mathrm{m}^{2}\right)$ determined in July to Dec. 2013 for different plants canopy surface area [width $\times$ width (square meters)]. 
The percentages of increase in growth index of plants (shrubs) in July to Dec. 2013 were 78.07, 84.72, 84.19, 66.12, and $50.47 \%$ for (Dodonaea ,Acalyphagodseffiana, Lantana camara, ,Jasminum and Bougainvilla) respectively (Fig.6).

Canopy dimensions were multiplied to calculate a growth index [GI = width $1 \times$ width $2 \times$ height (cubic meters)], to estimate canopy volume.

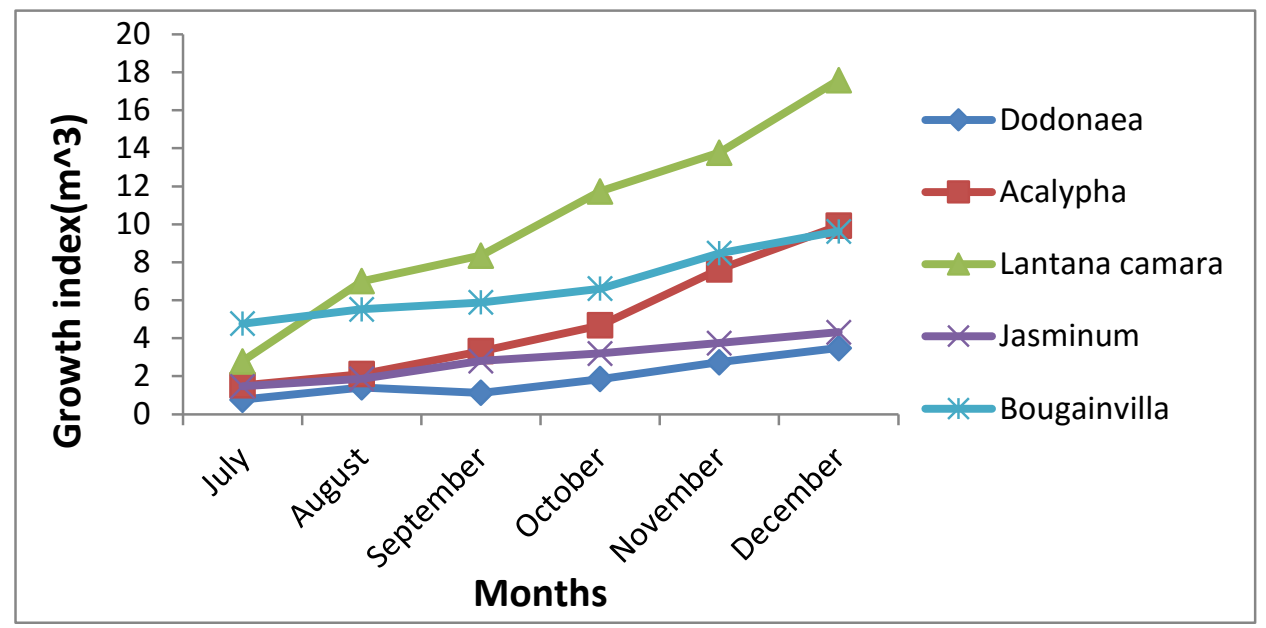

Fig. 6. Growth index $\left(\mathrm{m}^{3}\right)$ determined in July to Dec.2013 for different plants growth- index [GI $=$ width $1 \times$ width $2 \times$ height (cubic meters)].

\section{Estimation of water use.}

Due to the differences in plant size and leaf area, water use of plants was expressed in daily water use per case. Fig.7. indicate water use per case and compares with water use for reviews that do not use landscape coefficient, and use crop coefficient for landscape equal one and water use of plants $100 \%$ reference $\mathrm{ET}_{\mathrm{o}}$. Therefore, landscape coefficient $\left(\mathrm{K}_{\mathrm{L}}\right)$ of plants varies not only by plant species, but also by leaf area, growth rate and/or density factor. Without quantifying plant size, although microclimate is similar for the three cases.

The average daily plant water requirement when using $100 \%$ reference $\mathrm{ET}_{\mathrm{o}}$ compared with landscape coefficient to estimate average daily plant water requirement for each case were 60, 64 and $85 \%$ for (case1 ,case2 and case3) respectively (Fig.7).

Quality plant material is important in a successful evaluating implementation. Having good mental images of the growth habit and 
form native plant species have in their natural habitats will help in the evaluation process.

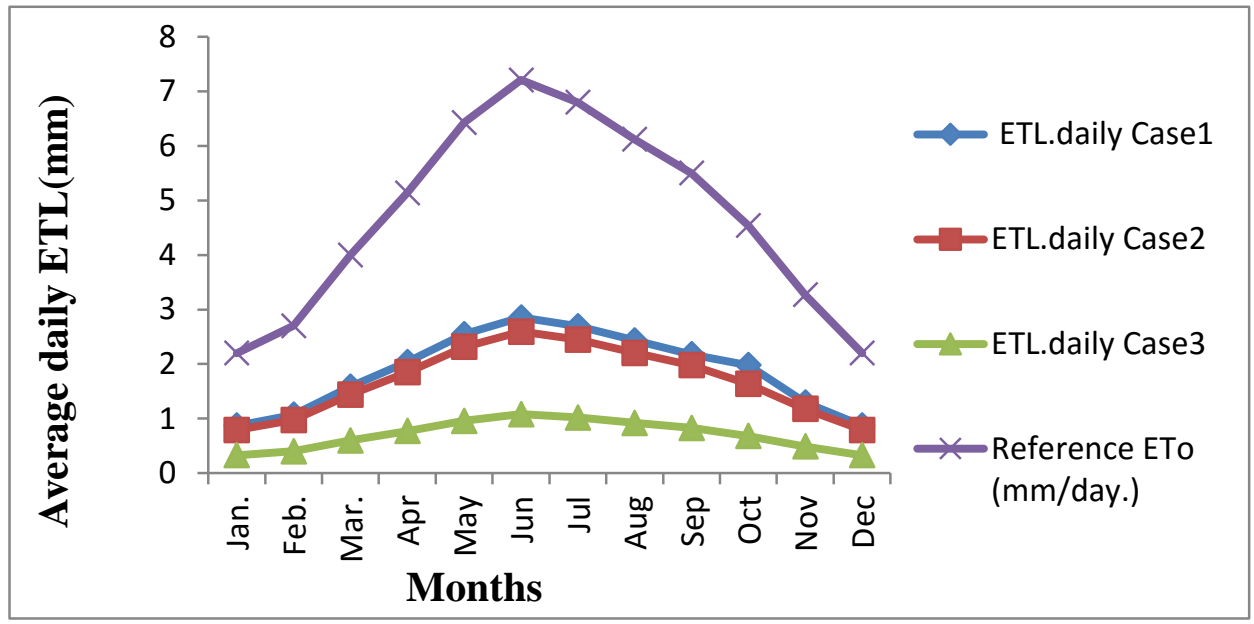

Fig. 7. Average daily plant water requirement (mm./day) monthly compared with reference $\mathrm{ET}_{\mathrm{o}}(\mathrm{mm} . / \mathrm{day})$.

\section{CONCLUSIONS}

This research provides an understanding of how values for each of the landscape coefficient factors are assigned and used. In addition, an appreciation for the diversity of species, differences in vegetation density, and variation in microclimates exists in landscapes. In many cases, there will be a different landscape coefficient for each irrigation zone.

The study recommends using "LIS" Program to determine the species factor $\mathrm{K}_{\mathrm{s}}$ of plants under consideration with the knowledge of other microclimate, and density factors. A guide for ornamental plants to calculate landscape coefficient and landscape evapotranspiration $\left(\mathrm{ET}_{\mathrm{L}}\right)$ is recommended. The "LIS" Program succeeded because it saved water, proved to be cost-effective. The results of this study will not only serve water specialist to estimate landscape requirement, but also help horticulture planner to choose plants having similar water use together on the same region.

\section{REFERENCES}

Awady , M. N., G. R .Vis , E. Kumar and S. Mitra . 2003. Distribution uniformity from pop-up sprinklers and landscape water-saving. Misr J. Ag. Eng. 20(4):181-194. 
Brown, P. 2000. Turf Irrigation Management Series: I, Basics of Evaporation and Evapotranspiration . U. of Arizona, Coll. of Ag. Tucson, Arizona : 4p.

Costello, L.R.,N.P. Matheny and J.R. Clark.1993.Estimating water requirements of landscape plantings, the landscape coefficient method, Crop. Ext., U .C. Div. Agr. and Natural Reso, Leaflet 21493.

IA.2005. Landscape irrigation scheduling and water management. The Irrigation Association - Water Manag. Com. USA. P:190.

Romero C. C. and M. D. Dukes.2009 . Turfgrass and Ornamental Plant Evapotranspiration and Crop Coefficient Literature Review. Ag. and Biol. Eng. Dep. U. of Florida Gainesville, FL. P:55.

Streich , A. , S. Rodie , R.Gaussoin.2003. Turf in the Landscape. Agriculture and Natural Resources at the University of NebraskaLincoln cooperating with the Counties and the USD A. p:4.

WUCOLS. 2000. A guide to estimating irrigation water of Landscape plantings in California, The landscape coefficient method and WUCOLS (Water Use Classification of Landscape Species) III. Cal Coop Ext, Cal Dept. of Water Resource, Bulletins and Reports. $\mathrm{P}: 152$.

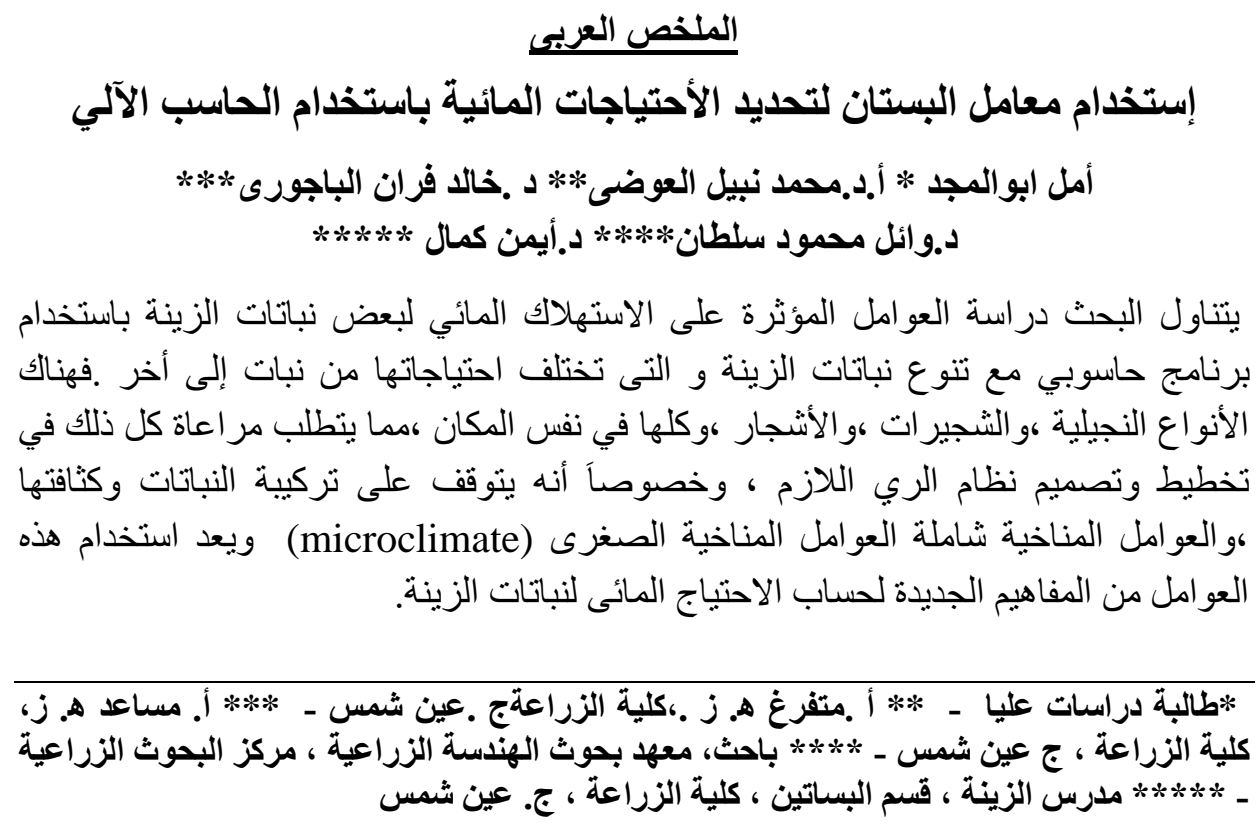




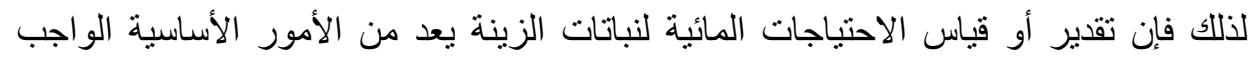

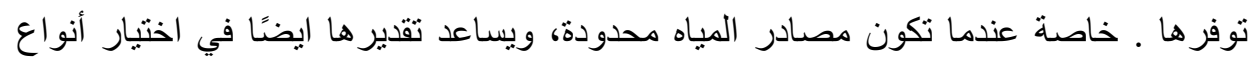
النباتات الملائمة للزر اعة. تتلخص أهم مخرجات البرنامج في: لئن

تحديد الاحتياجات المائية لكل نبات باستخدام المفهوم الجديد و هو معامل البستان (KL) و العوامل

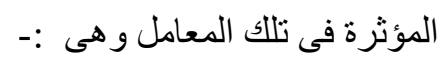

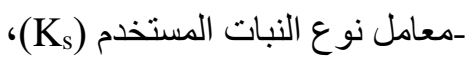

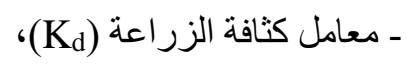

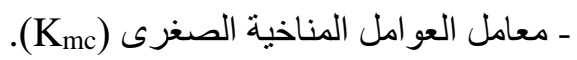

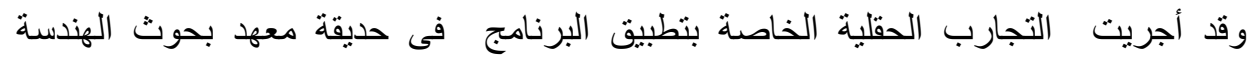

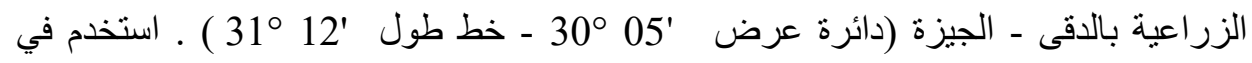

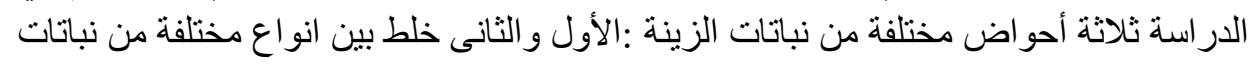

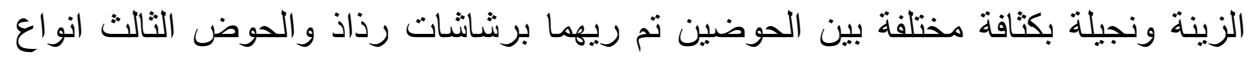

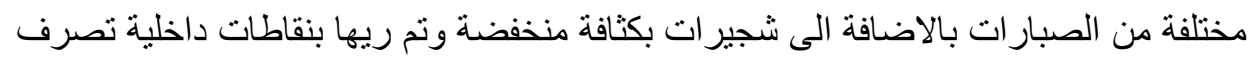

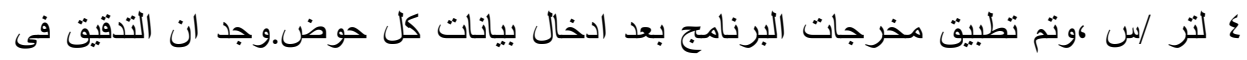

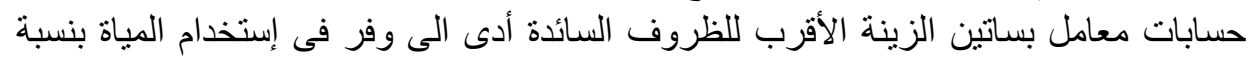

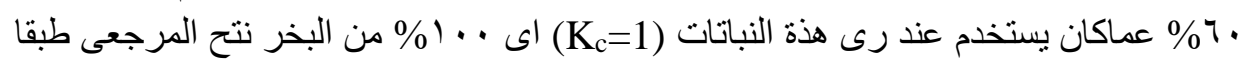

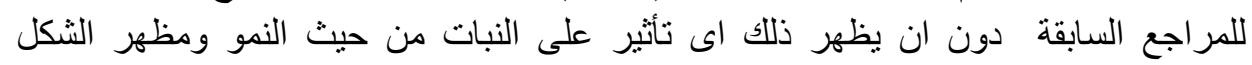

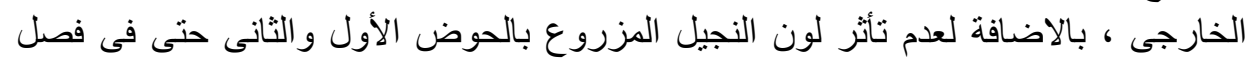

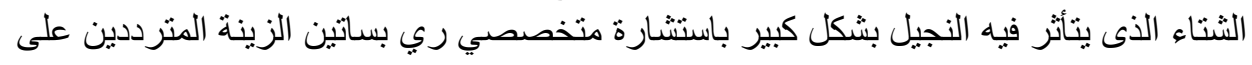

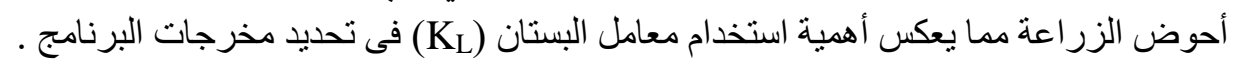

